\title{
Salix appendiculata (Salicaceae) found in the Western Carpathians in Slovakia
}

\author{
Peter KUČERA \\ Comenius University in Bratislava, Botanical Garden, workplace Blatnica \\ Blatnica 315, SK-038 15 Blatnica pri Martine, Slovakia \\ peter.kucera@uniba.sk
}

Kučera P. 2019. Salix appendiculata (Salicaceae) found in the Western Carpathians in Slovakia. Ukrainian Botanical Journal, 76(2): 162-166.

Abstract. During field research in 2017, two localities of Salix appendiculata were discovered in the Vel'ká Fatra Mts (central Slovakia, Western Carpathians). This species is not reported from the Western Carpathians in the recent floras and keys to the flora. The nearest localities of $S$. appendiculata are known in Austria. Its hybrid, $S$. ×attenuata, was recorded in the Vel'ká Fatra Mts as well.

Keywords: avalanche path, flora, Inner Western Carpathians, Salix appendiculata, Salix ×attenuata, Slovakia, Vel'ká Fatra Mts

Кучера П. 2019. Знахідка Salix appendiculata (Salicaceae) у Західних Карпатах із Словаччини. Український ботанічний журнал, 76(2): 162-166.

Університет ім. Коменського в Братиславі, Ботанічний сад

Блатніца, 315, SK-038 15 округа Мартін, Словаччина

Реферат. Під час польових досліджень, проведених у 2017 р., було виявлено два локалітети Salix appendiculata у гірському масиві Велика Фатра (центральна Словаччина, Західні Карпати). Повідомлення про знахідку цього виду в Західних Карпатах у нещодавно опублікованих флорах і визначниках не наводились. Найближчі до цих локалітетів знахідки $S$. appendiculata відомі з Австрії. Гібрид цього виду, S. ×attenuata, також відмічений на території масиву Велика Фатра.

Ключові слова: Велика Фатра, Внутрішні Західні Карпати, лавинний шлях, Salix appendiculata, Salix ×attenuata, Словаччина, флора

\section{Introduction}

Salix appendiculata Vill. is an European willow species distributed mainly in the Alps and adjacent mountain ranges located to the north - in the Jura Mountains, in the Black Forest [Schwarzwald] (Heß et al., 1967; Lautenschlager-Fleury, Lautenschlager, 1994; Jordan, Tison, 2014) as well as in the Bohemian Forest [Šumava/Böhmerwald] (Chmelař, Koblížek, 1990; Ekrt, Koutecký, 2013). Other parts of the species range (cf. Jalas, Suominen, 1976, map 232) are (1) the Balkan Peninsula with the scattered distribution from the Dinarides to the Rhodopes (Domac, 1950, 1989; Velchev, 1966; Christensen, 1997; Kailis, Flora Croatica Database, 2004-onward; Eleftheriadou, 2013), (2) the Apennines (Pignatti, 1982), and, questionably, (3) the Massif Central and the Pyrenees (Blanco, 1993;

(C) 2019 P. Kučera
Jordan, Tison, 2014). Kailis and Eleftheriadou (2013) summarized newer thoughts on reliability of some data on the distribution of this willow species.

Salix appendiculata is not listed in the Flora of Slovakia (Koblížek, 2006). There are also no available records of the species from Slovakia in the last edition of the key to united flora of Bohemia, Moravia, SW and S Upper Silesia, and Slovakia (Dostál, 1991) and in the Flora of Czech Republic (Chmelař, Koblížek, 1990). Heß et al. (1967) included the "Carpathians" in the distribution area of the species, though with a question mark. In the new monograph Willows of the Czech Republic (Vašut et al., 2013) it is stated that "... data from the Carpathians are apparently erroneous"; however, no further details on the assessed sources were given.

The aim of this contribution is to present records of Salix appendiculata and $S$. ×attenuata from the Vel'ká 


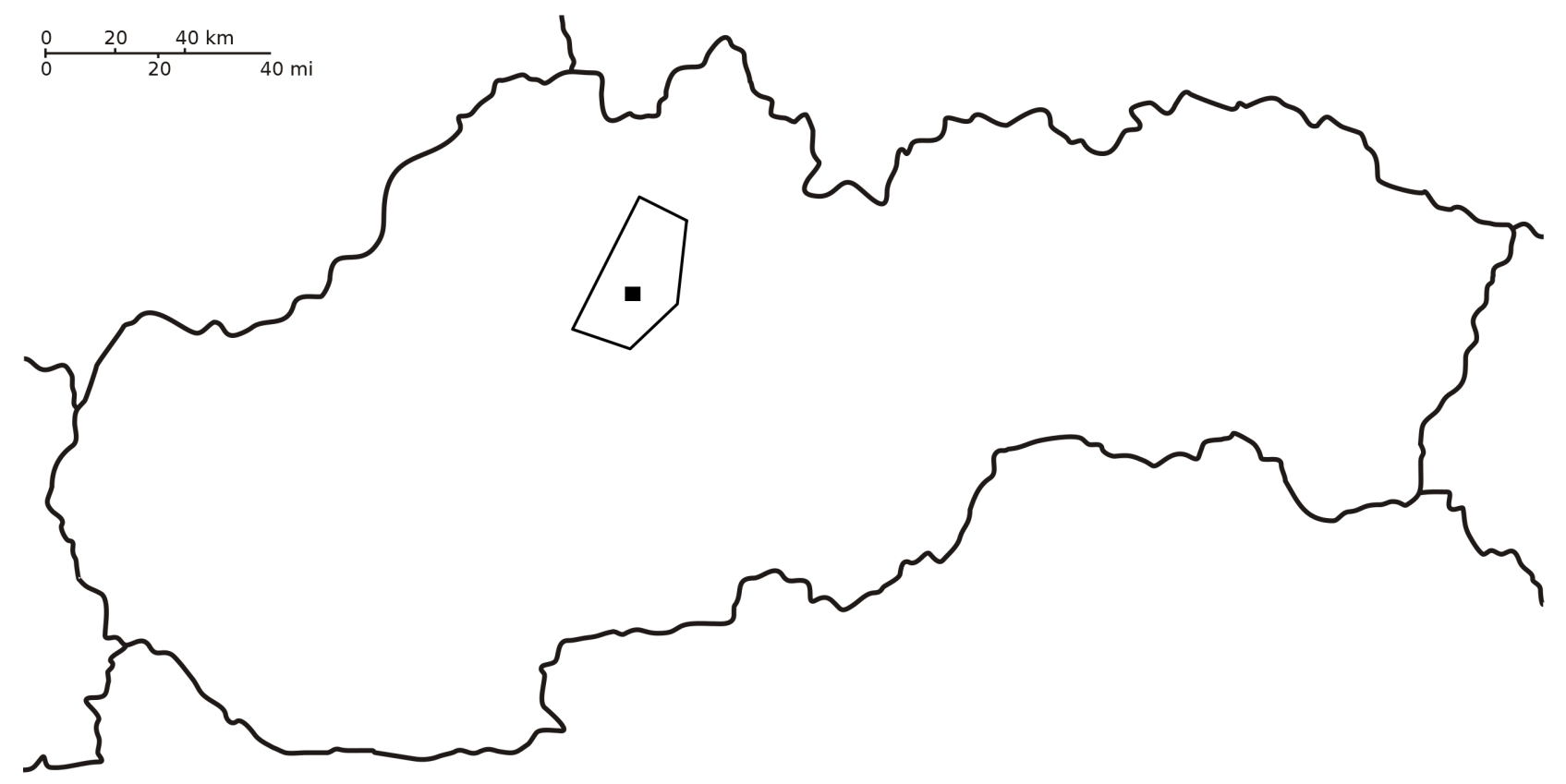

Fig. 1. Location of the locality of Salix appendiculata in Slovakia: polygon - Vel'ká Fatra Mts, black square - Borišov Mt.

Fatra Mts (central Slovakia, Western Carpathians). Plant names follow the checklist of Marhold et al. (1998), Salix names not mentioned in this checklist are given according to The International Plant Names Index (http://www.ipni.org/, accessed 3 November 2017) and some other sources (such as Plants of the World Online, http://www.plantsoftheworldonline.org/, accessed 13 February 2019). The morphological description mainly follows the format and terminology of Dostál and Futák (1966). Herbarium specimens are deposited in $\mathrm{BBZ}$ - reference herbarium of the Botanical Garden of Comenius University, workplace Blatnica (cf. Vozárová, Sutorý, 2001).

Locality and habitat of Salix appendiculata in the Vel'ká Fatra Mts

In August 2017, during a field research in the Vel'ká Fatra Mts (central Slovakia, Fig. 1) I found one shrub of Salix appendiculata (a polycormon). This locality (hereinafter referred to as "L1": N 48 56.796', E $19^{\circ} 5.362^{\prime}, \pm 11 \mathrm{~m}, 1,155 \mathrm{~m}$ a.s.1., 02.08.2017) is situated in the steep dell with the local name "Prvý Balov" on the northern slope of Borišov Mt. (1,509 $\mathrm{m}$ a.s.1.), an isolated mount in the central part of the mountain range, built by carbonate sedimentary formations of the Veporicum unit and the Tatricum unit (Polák et al., 1997).
The second locality of the species I have registered during another field survey in a spatially close site on the same slope of Borišov Mt. within the another dell called "Druhý Balov" (hereinafter referred to as "L2":

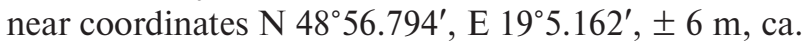
1,125 m a.s.1.,04.10.2017; approx. $250 \mathrm{~m}$ apart from L1; Fig. 2): two polycormons were growing there.

The species is not mentioned in the comprehensive flora of the Vel'ká Fatra Mts (Kliment et al., 2008). The closest known localities of $S$. appendiculata lie approximately $250 \mathrm{~km}$ to southwest in Austria, southwestwards from Vienna in the most northeastern ridges of the Alps (e.g., Schneeberg Mt., 08.07.2018, P. Kučera, BBZ).

Site L1 is in the side and site L2 in the bottom of narrow and steep avalanche paths facing to the north, with steep slopes, in the case of L2 with formation of small waterfalls. Surrounding forest vegetation is a montane fir-beech forest, higher on the slopes with transition to old secondary Norway spruce (Picea abies (L.) H. Karst.) stands.

Vegetation of the first Salix appendiculata locality (L1) is shaped by treeless tall-herb vegetation (frequent avalanches) dominated by Petasites kablikianus Tausch which is accompanied by P. albus Gaertn., Dryopteris filix-mas (L.) Schott, Athyrium filix-femina (L.) Roth, Delphinium elatum L., Valeriana excelsa Poir. subsp. 
sambucifolia (J.C.Mikan ex Pohl) Holub, Urtica dioica L., Impatiens noli-tangere L. In the lower herb layer are growing Dentaria bulbifera L. (= Cardamine bulbifera (L.) Crantz), Cortusa matthioli L. (= Primula matthioli (L.) V.A.Richt.), Stellaria nemorum L., Primula elatior (L.) Hill, Geum rivale L., and Chrysosplenium alternifolium L. Woody species are represented by Acer pseudoplatanus L., Ribes petraeum Wulfen, $R$. alpinum L., and Rosa pendulina L.

The second locality (L2) has a more rugged relief with abundant shrubs and mostly small young trees (Fraxinus excelsior L., Sorbus aucuparia L., S. aria (L.) Crantz (= Aria edulis (Willd.) M.Roem.), S. austriaca (Beck) Prain (= Hedlundia austriaca (Beck) Sennikov \& Kurtto) aggr., Fagus sylvatica L., Salix caprea L., Acer pseudoplatanus L., Ulmus glabra Huds., Daphne mezereum L.) and also more diversified vegetation and flora. Beside the above-mentioned species, the following taxa were found: Anthriscus nitida (Wahlenb.) Hazsl., Lunaria rediviva L., Polystichum aculeatum (L.) Roth, Gymnocarpium robertianum (Hoffm.) Newman, Cirsium erisithales Scop., Rubus idaeus L., Valeriana tripteris L., Filipendula ulmaria (L.) Maxim., Galium schultesii Vest, Myosotis sp. and others (02.08.2017, 04.10.2017, 04.07.2018). Both sites have a developed ground layer flora; however, moss and liverwort species were not sampled.

\section{Morphological description of $S$. appendiculata occur- ring in the Vel'ká Fatra Mts}

Selected morphological characters of the collected $S$. appendiculata specimens (deposited in BBZ) from the given sites L1 and L2:

- shrubs up to $5 \mathrm{~m}$ tall, branches brown-greyish, decorticated wood without elevated ridges,

- buds and one-year twigs pubescent, only very long terminal twigs somewhat glabrescent (basal half), older twigs glabrescent,

- leaves elongate to elliptic, widest in or near the middle, base cuneate to attenuate, apex cuneate to attenuate, often acuminate on long terminal twigs, leaf margin serrate,

- normally developed leaf blades (8.5) 9.5-12.5 (15) $\mathrm{cm}$ long, 3.5-4.5 (5) $\mathrm{cm}$ wide, more or less glabrescent above (primary vein pubescent until the leaf fall) and dark green, permanently pubescent beneath (densely on veins) and slightly bluish,

- petiole 10-15 (19) mm long, pubescent,

- leaf veins markedly impressed above and prominent beneath, number of secondary veins of half-blade more than (15) 17 (-25) (cf. Chmelař, Koblížek, 1990; Jordan, Tison, 2014),

- stipules well developed, especially on long terminal shoots large, shape irregular, margins coarsely dentate, caducous on short twigs, especially deeper in the shrub crown [similarly to those of $S$. caprea].

Occurrence of $S$. caprea at the second locality (L2) makes recognition and differentiation of $S$. appendiculata on the locality much easier (S. caprea having wide elliptic, shorter, brighter leaves, with smaller number of secondary veins, apex and base \pm obtuse). Another remarkable attribute is a different phenological development of the two species: while $S$. appendiculata was here until the date 04.10.2017 still with dark green leaves, brighter green colour of $S$. caprea leaves was already longer fading away as the species was closer before leaf fall.

Salix appendiculata descriptions from the Czech Republic (Chmelař, Koblížek, 1990; Vašut et al., 2013) and Austria (Fischer et al., 2008) specify the occurrence of weakly developed elevated ridges on the decorticated wood of twigs. However, this is not the case of other surveys where the decorticated wood is described as flat, without ridges (Heß et al., 1967; LautenschlagerFleury, Lautenschlager, 1994; Jordan, Tison, 2014). I suppose that individuals with ridges from the Czech Republic are hybrids/hybridogeneous specimens of S. appendiculata (without ridges) and $S$. aurita (with ridges).

\section{Hybrid of $\boldsymbol{S}$. appendiculata in the Vel'ká Fatra}

Near the second locality (L2) of $S$. appendiculata in the Vel'ká Fatra, two (tree-formed) shrubs of $S$. appendiculata $\times S$. caprea $(=S$. $\times$ attenuata Kern.; syn. $S . \times$ macrophylla Kern., nom. illeg.; Kerner, 1860) are growing. The second of the two individuals (its location - L3: N 48 $56.811^{\prime}$, E $19^{\circ} 5.179^{\prime}, \pm 12 \mathrm{~m}, 1,110 \mathrm{~m}$ a.s.1.,04.10.2017) developed several treelike stems: due to unstable background the oldest stem is spread above the soil surface of the steep slope and the newest one is entirely upright.

A remarkable feature of this hybrid is its distinct leaf morphology: while the fast-growing long terminal twigs have leaves similar in their shape to those of S. appendiculata, leaf margins more coarsely serrate, leaves of the short twigs are, especially in the lower half of the crown, morphologically close to those of $S$. caprea. Leaf colour and the autumn phenology are more similar to those of $S$. caprea. 


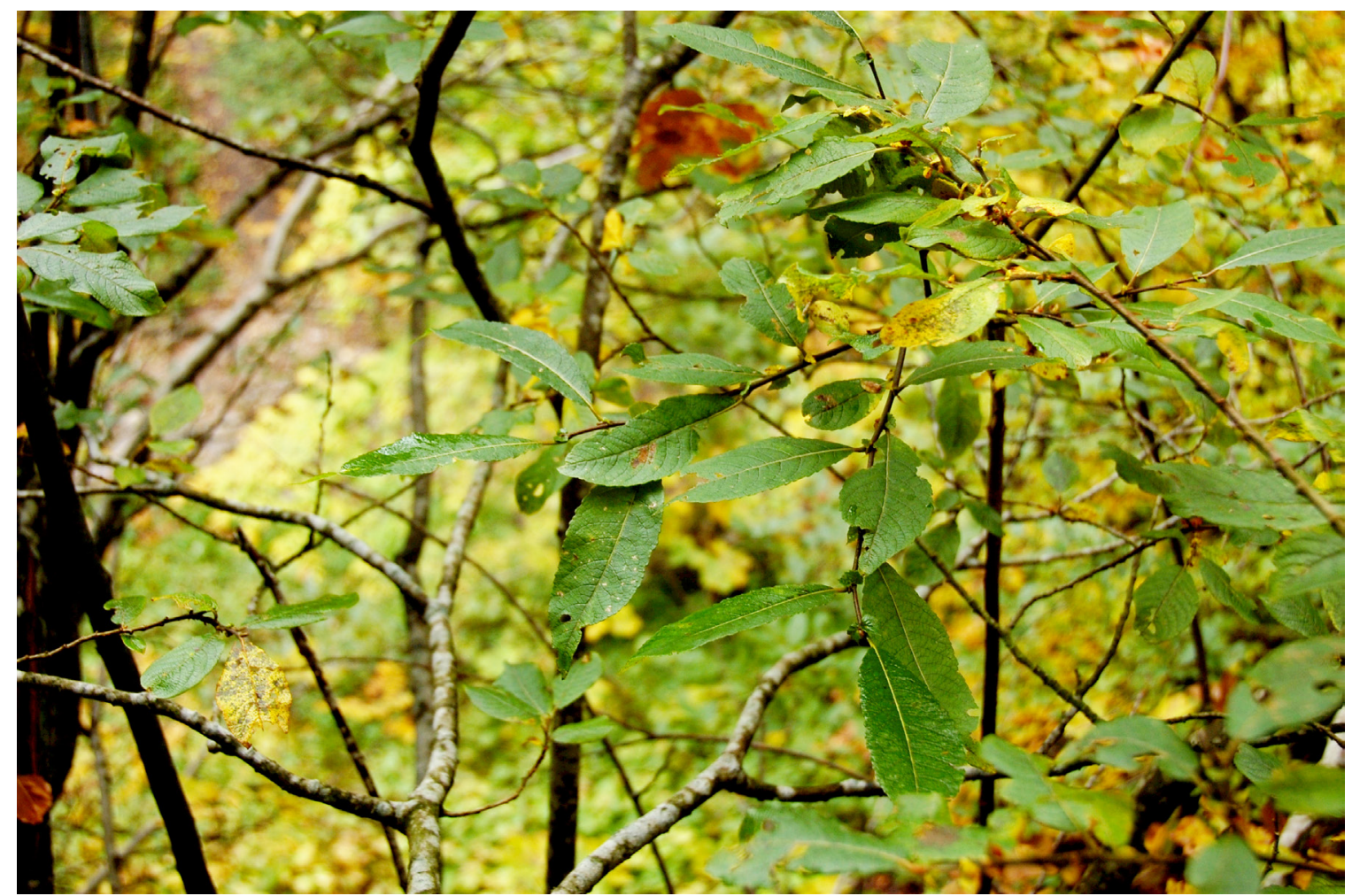

Fig. 2. Leaves of Salix appendiculata. Photo by P. Kučera, 04.10.2017

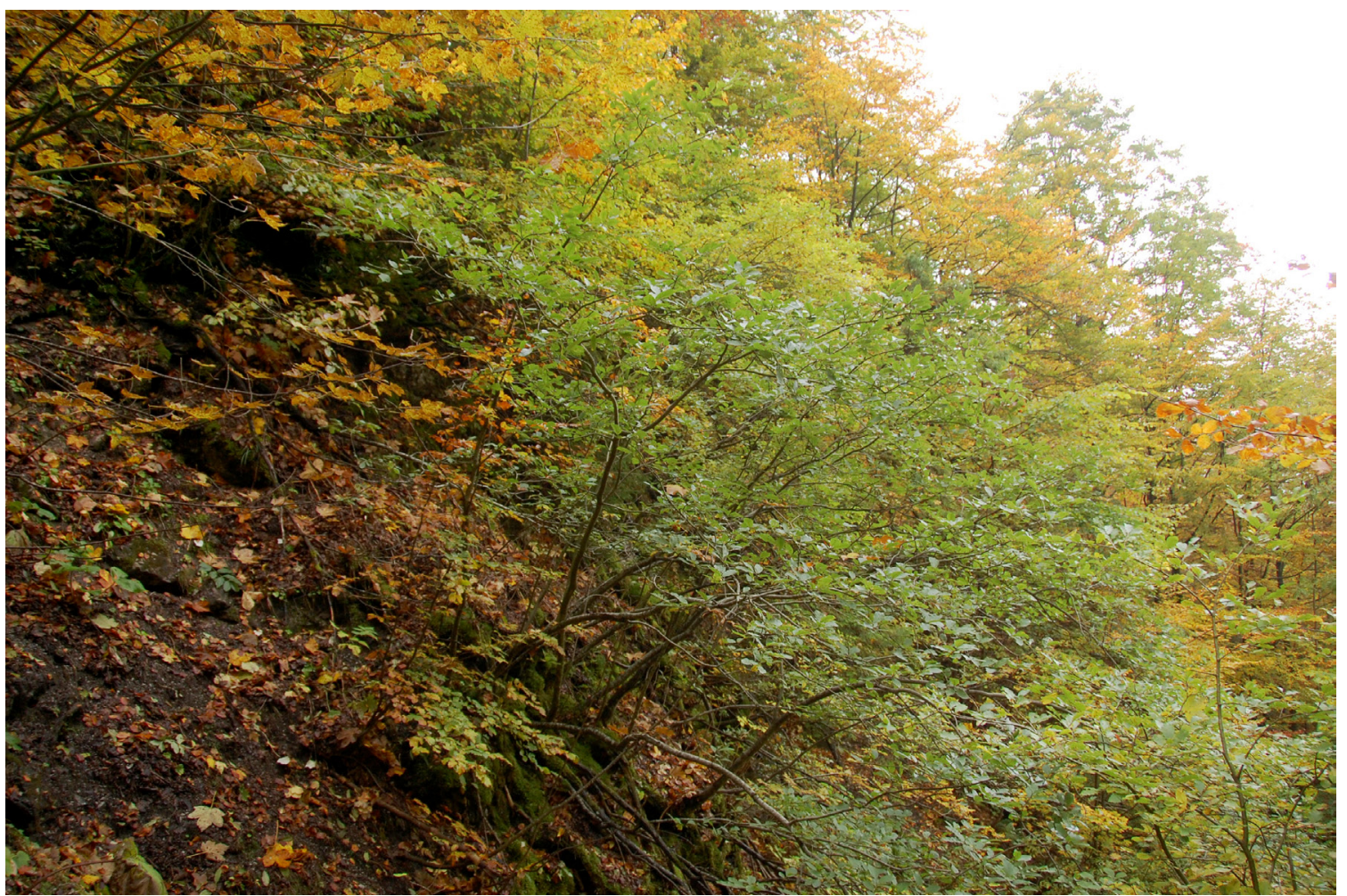

Fig. 3. Growth form of Salix appendiculata. Photo by P. Kučera, 04.10.2017 
Salix $\times$ attenuata was identified also on the other two localities of Borišov slopes (L4: N 48 56.493', E $19^{\circ} 5.807^{\prime}, \pm 6 \mathrm{~m}, 1,260 \mathrm{~m}$ a.s.1., 04.10.2017, P. Kučera, BBZ; L5: N 4856.482', E $19^{\circ} 5.840^{\prime}, \pm 6$ m, $1,265 \mathrm{~m}$ a.s.1.,04.10.2017, P. Kučera, not.). Occurrence of $S$. $\times$ attenuata will be surely discovered on other localities throughout the mountain range of the Vel'ká Fatra Mts; however, great effort should be put on a reliable identification and differentiation of $S$. caprea from S. $\times$ attenuata as variability of the latter is high due to its long-term hybridization.

\section{Acknowledgements}

This study was partially supported by the Slovak grant agency VEGA, project No. 2/0119/19. I also greatly appreciate useful comments provided by both reviewers, as well as editorial comments and improvement of my English by Sergei Mosyakin (M.G. Kholodny Institute of Botany, National Academy of Sciences of Ukraine, Kyiv, Ukraine).

\section{REFERENCES}

Blanco P. 1993. Salix L. In: Flora iberica: Plantas vasculares de la Península Ibérica e Islas Baleares, vol. 3, Plumbaginaceae (partim)-Capparaceae. Eds S. Castroviejo, C. Aedo, S. Cirujano, M. Laínz, P. Montserrat, R. Morales, F. Muñoz Garmendia, C. Navarro, J. Paiva, C. Soriano. Madrid: Real Jardín Botánico, C.S.I.C, pp. $477-517$.

Chmelař J., Koblížek J. 1990. Salicaceae Mirbel - vrbovité. In: Květena České republiky, sv. 2. Eds S. Hejný, B. Slavík. Praha: Academia, pp. 458-495.

Christensen K.I. 1997. Salix L., nom. cons. prop. In: Flora Hellenica, vol. 1. Eds A. Strid, K. Tan. Königstein: Koeltz Scientific Books, pp. 27-33.

Domac R. 1950. Flora za određivanje i upoznavanje bilja. Zagreb: Izdavački zavod Jugoslavenske akademije znanosti i umjetnosti, 552 pp.

Domac R. 1989. Mala flora Hrvatske i susjednih područja. 4. izd. Zagreb: Školska knjiga, 544 pp.

Dostál J. 1991. Vel'ký klúč na určovanie vyššich rastlín, vol. 1. Bratislava: Slovenské pedagogické nakladatel'stvo, $776 \mathrm{pp}$.

Dostál J., Futák J. 1966. Morfologická terminológia. In: Flóra Slovenska, zv. 1. Ed. J. Futák. Bratislava: Vydavatel'stvo Slovenskej akadémie vied, Všeobecná čast', pp. 27-530.

Ekrt L., Koutecký P. 2013. Salix appendiculata Vill. - vrba velkolistá. In: Červená kniha květeny jižní části Čech., Bd 1. Eds P. Lepší, M. Lepší, K. Boublík, M. Štech, V. Hans. České Budějovice: Jihočeské muzeum v Českých Budějovicích, pp. 371.

Flora Croatica Database. 2004-onward. Available at: http:// hirc.botanic.hr/fcd (Accessed 3 November 2017).

Heß E., Landolt E., Hirzel R. 1967. Flora der Schweiz und angrenzender Gebiete. Basel; Stuttgart: Birkäuser Verlag, $860 \mathrm{pp}$.
Jalas J., Suominen J. 1976. Atlas Florae Europaeae. Distribution of Vascular Plants in Europe, vol. 3. Helsinki: The Committee for Mapping the Flora of Europe; Societas Biologica Fennica Vanamo, 128 pp.

Jordan D., Tison J.-M. 2014. Salix L. In: Flora Gallica: Flore de France. Ed. J.-M. Tison. Première éd., deuxième tirage corrigé. Méze: Biotope Éditions, pp. 1032-1038.

Kailis N., Eleftheriadou E. 2013. On the occurrence of Salix appendiculata (Salicaceae) in Greece. Willdenowia, 43(2): 257-261. https://doi.org/10.3372/wi.43.43204

Kerner A. 1860. Niederösterreichische Weiden II. [(specieller) Theil]. In: Verhandlungen der KaiserlichKöniglichen Zoologisch-Botanischen Gesellschaft in Wien, 10: 179-282. Available at: https://www.biodiversitylibrary.org/bibliography/13275\#/summary (Accessed 18 January 2018).

Kliment J. [ed.], Lisická E., Šoltés R., Bernátová D., Dítě D., Janišová M., Jarolímek I., Kochjarová J. Kubinská A., Kučera P., Mišíková K., Obuch J., Pišút I., Topercer J., Uhlírová J., Zaliberová M. 2008. Príroda Vel'kej Fatry: Lišajniky, machorasty, cievnaté rastliny. Bratislava: Vydavatel'stvo Univerzity Komenského, 408 pp.

Kobližek J. 2006. Salix L. In: Flóra Slovenska, zv. 3. Eds K. Goliašová, E. Michalková. Bratislava: VEDA, vydavatel'stvo Slovenskej akadémie vied, pp. 209-290.

Lautenschlager-Fleury D., Lautenschlager E. 1994. Die Weiden von Mittel- und Nordeuropa: Bestimmungschlïssel und Artbeschreibung für die Gattung Salix L. Überarb. erw. Neuaufl. [Softcover reprint of the hardcover $2^{\text {nd }}$ edition 1994]. Basel: Springer, 180 pp. https://doi. org/10.1007/978-3-0348-5623-2

Marhold K., Goliašová K., Hegedüšová Z., Hodálová I., Jurkovičová V., Kmet’ová E., Letz R., Michalková E., Mráz P., Peniašteková M., Š́pošová H., Ťavoda O. et al. 1998. Paprad'orasty a semenné rastliny. In: Zoznam nižšich a vyššich rastlin Slovenska. Eds K. Marhold, F. Hindák. Bratislava: VEDA, vydavatel'stvo Slovenskej akadémie vied, pp. 333-687.

Pignatti S. 1982. Salix L. - Salice (1873). In: Flora d' Italia, vol. 1. Ed. S. Pignatti. Bologna: Edagricole, pp. 89-105.

Polák M., Bujnovský A., Kohút M. [eds]. 1997. Geologická mapa Vel'kej Fatry. Bratislava: Ministerstvo životného prostredia Slovenskej republiky, 2 maps.

Vašut R. J., Sochor M., Hroneš M., Brandová B., Klečková L., Nývltová V., Ševčík J. 2013. Vrby České republiky. Olomouc: Univerzita Palackého v Olomouci, 104 pp.

Velchev V. 1966. Salicaceae. In: Flora na Narodna Republika Bălgarija, vol. 3. Ed. D. Jordanov. Sofija: Izdatelstvo na Bălgarskata akademia na naukite, pp. 39-84. [Велчев В. 1966. Върбови - Salicaceae Lindl. В кн.: Флора на Народна Република България, т. 3. Ред. Д. Йорданов. София: Издателство на Българската академия на науките, с. 39-84].

Vozárová M., Sutorý K. 2001. Index herbariorum Reipublicae bohemicae et Reipublicae slovacae. Zprávy Ceské Botanické Společnosti (Praha), 36, Př́loha 2001/1 \& Bulletin Slovenskej botanickej spoločnosti, Suppl. 7: 1-96.

Recommended for publication by $\quad$ Submitted 26.11.2018 S.L. Mosyakin 